\title{
Congenital methaemoglobinaemia presenting in a 55-year-old man
}

\author{
Leila Izadi Firouzabadi 두, ${ }^{1}$ Paul Mead ${ }^{2}$
}

${ }^{1}$ Dermatology Department, North Cumbria Integrated Care NHS Foundation Trust, Carlisle, UK

${ }^{2}$ General Medicine Department, North Cumbria Integrated Care NHS Foundation Trust, Whitehaven, UK

\section{Correspondence to} Dr Leila Izadi Firouzabadi; lilaizadi@yahoo.com

Accepted 24 July 2020

\section{Check for updates}

(C) BMJ Publishing Group Limited 2020. No commercial re-use. See rights and permissions. Published by BMJ.

To cite: Izadi Firouzabadi L, Mead P. BMJ Case Rep

2020;13:e236677.

doi:10.1136/bcr-2020-

236677

\section{DESCRIPTION}

We present the case of a 55-year-old man admitted with influenza-like symptoms together with a nonproductive cough. Past medical history was of renal failure of uncertain aetiology, kidney transplantation in 1998, thyroid cancer with thyroidectomy in 1999, cardiac ablation for atrial fibrillation in 2005 and sleep apnoea. On examination he was feverish at $38^{\circ} \mathrm{C}$ and centrally cyanosed (figure $1 \mathrm{~A}, \mathrm{~B}$ ). Oxygen saturation was $89 \%$ on $15 \mathrm{~L}$ of oxygen, blood gases revealed a $\mathrm{PO}_{2}$ of 36 together with a methaemoglobin of $15 \%$. Chest X-ray was unremarkable. Initial treatment was with intravenous antibiotics, Tamiflu as well as intensive treatment unit transfer. Treatment of his methaemoglobinaemia was considered however for a number of reasons this was withheld including that he was taking a selective serotonin reuptake inhibitor, that he did not seem unduly distressed and that on further questioning he stated he had blue lips, tip of nose and fingertips for many years, raising the possibility of congenital methaemoglobinaemia. He later reported abdominal pain. CT of abdomen revealed a perforated duodenal ulcer with an associated complex fluid collection. Treatment was conservative with full recovery.

Investigation of this man's methaemoglobinaemia revealed no recent history of taking any medications associated with acquired methaemoglobinaemia, haemoglobin electrophoresis was unremarkable and he did not have G6PDH deficiency. Subsequent enzyme testing showed that he had normal pyruvate kinase activity but was found to have low NADHcytochrome b5 reductase activity confirming the diagnosis of congenital methaemoglobinaemia.

Congenital methaemoglobinaemia is a rare autosomal recessive condition which is due to cytochrome b5 reductase (Cyb5R) deficiency, deficiency of cytochrome b5 or haemoglobin $\mathrm{M}$ disease. ${ }^{1}$ Two types of Cyb5R reductase deficiency have been defined where type I is as a result of this enzyme deficiency in only erythrocytes and in type II, the enzyme is deficient in all tissues. $^{2}$

While the symptoms are very mild in type I and the patients have a normal life expectancy, type II which is less common leads to a neurological dysfunction as well as a cyanosis and a significant reduced life span. ${ }^{3}$

Patients with type I Cyb5R deficiency often present with mild cyanosis in childhood and are often asymptomatic. It is unusual to be diagnosed late in life with only two other cases been described presenting after the age of $50 .^{3}$ Patients with congenital disease develop physiological compensatory mechanisms

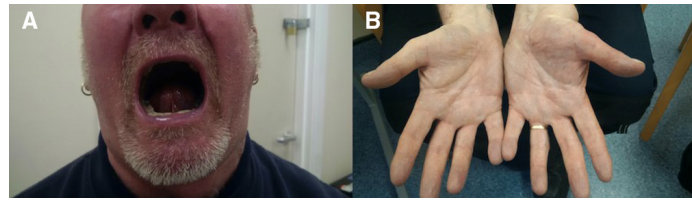

Figure $1 \quad(A, B)$ Cyanotic features of lips and hands.

Learning points

- Central cyanosis as opposed to peripheral cyanosis is always pathological.

- Modern blood gas analysers detect methaemoglobin level.

- Duration of cyanosis and drug history are important in patients presenting with methaemoglobinaemia to distinguish congenital versus acquired disease.

such as erythrocytosis and can tolerate elevated levels of methaemoglobin (up to $40 \%$ ) without symptoms. However, they may develop other symptoms such as shortness of breath and fatigue later in life due to age-related decline in cardiorespiratory physiology. Our patient has only recently developed shortness of breath having previously been an active participant in the transplant games for a number of years following his successful kidney transplant in 1998. No doubt this relates to age-related decline in cardiorespiratory reserve and additional comorbidities including the development of sleep apnoea. It is difficult to explain why his central cyanosis was not picked up earlier given his multiple comorbidities and medical variations. This may be due to factors such as been a mild genetic variant and that while suffering from renal failure, his cyanosis was less obvious due to anaemia resulting in a reduction of the absolute amount of methaemoglobin as this determines cyanosis rather than percentage alone. There is a chance of developing the significant symptoms if they have an exposure to oxidising agents. ${ }^{3}$ Our patient did not have a history of methaemoglobinaemia in his family.

Methylene blue is required in those who have the significant symptoms. ${ }^{2}$

Contributors PM was involved in patient management and made a revision to the article. LIF designed and drafted work.

Funding The authors have not declared a specific grant for this research from any funding agency in the public, commercial or not-for-profit sectors.

Competing interests None declared.

Patient consent for publication Obtained. 
Provenance and peer review Not commissioned; externally peer reviewed.

\section{ORCID iD}

Leila Izadi Firouzabadi http://orcid.org/0000-0001-5385-6273

\section{REFERENCES}

1 Ward J, Motwani J, Baker N, et al. Congenital methemoglobinemia identified by pulse oximetry screening. Pediatrics 2019;143:e20182814.

2 Viršilas E, Timukienè L, Liubšys A. Congenital methemoglobinemia: rare presentation of cyanosis in newborns. Clin Pract 2019;9:1188.

3 Soliman DS, Yassin M. Congenital methemoglobinemia misdiagnosed as polycythemia vera: case report and review of literature. Hematol Rep 2018;10:7221

Copyright 2020 BMJ Publishing Group. All rights reserved. For permission to reuse any of this content visit

https://www.bmi.com/company/products-services/rights-and-licensing/permissions/

BMJ Case Report Fellows may re-use this article for personal use and teaching without any further permission.

Become a Fellow of BMJ Case Reports today and you can:

- Submit as many cases as you like

Enjoy fast sympathetic peer review and rapid publication of accepted articles

- Access all the published articles

Re-use any of the published material for personal use and teaching without further permission

Customer Service

If you have any further queries about your subscription, please contact our customer services team on +44 (0) 2071111105 or via email at support@bmj.com.

Visit casereports.bmj.com for more articles like this and to become a Fellow 